\title{
PULMONARY VASCULAR CHANGES IN PULMONARY STENOSIS WITH AND WITHOUT VENTRICULAR SEPTAL DEFECT*
}

\author{
BY \\ M. A. THOMAS \\ From the Department of Pathology, University of Singapore \\ Received February 3, 1964
}

The status of the pulmonary vessels in patients with large shunts between the two circulations has been extensively studied (Dammann and Ferencz, 1956a; Heath and Whitaker, 1955; Edwards, 1957). In contrast, the pulmonary vasculature in cases with tetralogy of Fallot and pulmonary stenosis with intact ventricular septum has received scant attention and there has been no unanimity of opinion as to whether there are any changes at all in the pulmonary vessels in these cases, the nature of the changes, when they appear, and their significance.

As complete surgical correction of these defects is being practised in many centres, this study was undertaken to see whether, during the natural history of these conditions, pulmonary vascular changes occurred; and if so at what age these changes were histologically considered irreversible.

The normal evolution of the pulmonary vasculature from the fœtal to the adult type has been well described by Civin and Edwards (1951) and Dammann and Ferencz (1956b). One of the factors responsible for this normal process is an adequate flow of blood through the pulmonary trunk. If the blood flow to the lungs is greatly increased as a result of large extracardiac or intracardiac shunts, the normal process may be arrested or altered. If, on the other hand, the flow is diminished, as in cases of severe pulmonary stenosis or atresia, the normal process may again be delayed, arrested, or altered.

\section{SubJECTS AND MethodS}

Studies were carried out on 76 cases at necropsy. Of these, 50 had tetralogy of Fallot and 26 had pulmonary stenosis with intact ventricular septum. The ages ranged from 1 month to 32 years. Among the cases with tetralogy, 3 had pulmonary atresia. Of the 76 cases, only 15 had any surgical intervention and they died soon after operation, while the rest died of diverse causes.

In each case the size of the pulmonary or infundibular ostium was measured, and the stenosis was classified as mild, moderate, or severe. The size of the ventricular septal defect was noted as small, medium, or large.

The presence of bronchial and/or other collateral vessels and their size were also noted, and these were classified as minimal when only minute twigs were observed, and adequate when branches were found without any difficulty.

The lungs were fixed in 10 per cent formol calcium and a minimum of six sections from different areas of each lung were examined. Sections were stained using hæmatoxylin and eosin and Verhoeff-van Gieson techniques. Attention was specially directed to the structure of the muscular arteries and arterioles. The walls of these vessels and their lumina were studied and the pulmonary vasculature classified as 0 , I, II, and III according to the over-all predominant picture (see explanatory note below the Tables).

* Paper presented at the Annual General Meeting of the College of Pathologists of Australia, held in Adelaide in August 1961. 
TABLE I

Development of Collaterals and Pulmonary Vascular Changes in Pulmonary Stenosis with V.S.D.

\begin{tabular}{|c|c|c|c|c|c|}
\hline Case No. & Age and sex & Pulm. stenosis & V.S.D. & Collaterals & Pulm. vasculature \\
\hline $\begin{array}{r}1 \\
2 \\
3 \\
4 \\
5 \\
6 \\
7 \\
8 \\
9 \\
10 \\
11 \\
12 \\
13 \\
14 \\
15 \\
16 \\
17 \\
18 \\
19 \\
* 20 \\
21 \\
22 \\
23 \\
24 \\
* 25 \\
26 \\
* 27 \\
* 28 \\
29 \\
30 \\
31 \\
* 32 \\
* 33 \\
34 \\
* 35 \\
36 \\
* 37 \\
38 \\
* 39 \\
40 \\
41 \\
442 \\
43 \\
44 \\
45 \\
46 \\
47 \\
48 \\
49 \\
50\end{array}$ & \begin{tabular}{cc}
\multicolumn{3}{c}{ Months } \\
1 & $\mathrm{M}$ \\
1 & $\mathrm{M}$ \\
4 & $\mathrm{~F}$ \\
6 & $\mathrm{M}$ \\
6 & $\mathrm{M}$ \\
6 & $\mathrm{M}$ \\
8 & $\mathrm{M}$ \\
8 & $\mathrm{~F}$ \\
8 & $\mathrm{~F}$ \\
9 & $\mathrm{M}$ \\
10 & $\mathrm{M}$ \\
10 & $\mathrm{M}$ \\
11 & $\mathrm{~F}$ \\
12 & $\mathrm{M}$ \\
15 & $\mathrm{~F}$ \\
15 & $\mathrm{M}$ \\
16 & $\mathrm{M}$ \\
18 & $\mathrm{~F}$ \\
18 & $\mathrm{~F}$ \\
20 & $\mathrm{~F}$ \\
24 & $\mathrm{M}$ \\
24 & $\mathrm{~F}$ \\
24 & $\mathrm{~F}$ \\
Years \\
3 & $\mathrm{M}$ \\
3 & $\mathrm{M}$ \\
3 & $\mathrm{M}$ \\
4 & $\mathrm{M}$ \\
4 & $\mathrm{M}$ \\
5 & $\mathrm{M}$ \\
5 & $\mathrm{~F}$ \\
5 & $\mathrm{M}$ \\
6 & $\mathrm{~F}$ \\
6 & $\mathrm{~F}$ \\
6 & $\mathrm{M}$ \\
7 & $\mathrm{M}$ \\
7 & $\mathrm{M}$ \\
7 & $\mathrm{M}$ \\
8 & $\mathrm{~F}$ \\
10 & $\mathrm{M}$ \\
10 & $\mathrm{~F}$ \\
10 & $\mathrm{M}$ \\
15 & $\mathrm{M}$ \\
15 & $\mathrm{~F}$ \\
16 & $\mathrm{M}$ \\
16 & $\mathrm{~F}$ \\
18 & $\mathrm{M}$ \\
20 & $\mathrm{M}$ \\
20 & $\mathrm{~F}$ \\
25 & $\mathrm{M}$ \\
28 & $\mathrm{M}$
\end{tabular} & $\begin{array}{l}\text { Atresia } \\
\text { Atresia } \\
\text { Atresia } \\
\text { Severe } \\
\text { Mild } \\
\text { Moderate } \\
\text { Severe } \\
\text { Mild } \\
\text { Mild } \\
\text { Severe } \\
\text { Mild } \\
\text { Mild } \\
\text { Severe } \\
\text { Mild } \\
\text { Severe } \\
\text { Moderate } \\
\text { Moderate } \\
\text { Moderate } \\
\text { Moderate } \\
\text { Severe } \\
\text { Mild } \\
\text { Moderate } \\
\text { Moderate } \\
\text { Moderate } \\
\text { Severe } \\
\text { Severe } \\
\text { Severe } \\
\text { Mild } \\
\text { Moderate } \\
\text { Mild } \\
\text { Severe } \\
\text { Moderate } \\
\text { Severe } \\
\text { Moderate } \\
\text { Severe } \\
\text { Severe } \\
\text { Mild } \\
\text { Severe } \\
\text { Severe } \\
\text { Moderate } \\
\text { Moderate } \\
\text { Severe } \\
\text { Moderate } \\
\text { Mild } \\
\text { Moderate } \\
\text { Moderate } \\
\text { Moderate } \\
\text { Severe } \\
\text { Severe } \\
\text { Severe } \\
\text { Mode }\end{array}$ & $\begin{array}{l}\text { Large } \\
\text { Small } \\
\text { Medium } \\
\text { Large } \\
\text { Medium } \\
\text { Medium } \\
\text { Small } \\
\text { Small } \\
\text { Medium } \\
\text { Large } \\
\text { Large } \\
\text { Large } \\
\text { Medium } \\
\text { Large } \\
\text { Large } \\
\text { Small } \\
\text { Small } \\
\text { Medium } \\
\text { Large } \\
\text { Large } \\
\text { Large } \\
\text { Small } \\
\text { Small } \\
\\
\text { Medium } \\
\text { Small } \\
\text { Medium } \\
\text { Small } \\
\text { Large } \\
\text { Medium } \\
\text { Large } \\
\text { Medium } \\
\text { Small } \\
\text { Medium } \\
\text { Small } \\
\text { Small } \\
\text { Medium } \\
\text { Large } \\
\text { Small } \\
\text { Medium } \\
\text { Small } \\
\text { Small } \\
\text { Large } \\
\text { Small } \\
\text { Medium } \\
\text { Small } \\
\text { Small } \\
\text { Large } \\
\text { Small } \\
\text { Small } \\
\text { Medium }\end{array}$ & $\begin{array}{l}\text { Minimal } \\
\text { Minimal } \\
\text { Minimal } \\
\text { Minimal } \\
\text { Adequate } \\
\text { Minimal } \\
\text { Minimal } \\
\text { Minimal } \\
\text { Minimal } \\
\text { Adequate } \\
\text { Minimal } \\
\text { Adequate } \\
\text { Adequate } \\
\text { Minimal } \\
\text { Adequate } \\
\text { Adequate } \\
\text { Minimal } \\
\text { Adequate } \\
\text { Adequate } \\
\text { Minimal } \\
\text { Minimal } \\
\text { Minimal } \\
\text { Adequate } \\
\\
\text { Adequate } \\
\text { Minimal } \\
\text { Adequate } \\
\text { Minimal } \\
\text { Adequate } \\
\text { Adequate } \\
\text { Adequate } \\
\text { Adequate } \\
\text { Minimal } \\
\text { Adequate } \\
\text { Adequate } \\
\text { Minimal } \\
\text { Adequate } \\
\text { Minimal } \\
\text { Adequate } \\
\text { Minimal } \\
\text { Adequate } \\
\text { Adequate } \\
\text { Minimal } \\
\text { Adequate } \\
\text { Adequate } \\
\text { Minimal } \\
\text { Minimal } \\
\text { Adequate } \\
\text { Minimal } \\
\text { Minimal } \\
\text { Minimal }\end{array}$ & $\begin{array}{c}\text { O } \\
0 \\
\text { I } \\
\text { I } \\
0 \\
\text { I } \\
\text { I } \\
0 \\
\text { I } \\
0 \\
\text { I } \\
0 \\
0 \\
0 \\
0 \\
0 \\
\text { I } \\
0 \\
0 \\
\text { I } \\
0 \\
\text { I } \\
0 \\
\\
0 \\
\text { I } \\
0 \\
\text { I } \\
0 \\
0 \\
0 \\
0 \\
\text { I } \\
0 \\
0 \\
\text { I } \\
0 \\
\text { I } \\
0 \\
\text { II } \\
0 \\
0 \\
\text { II } \\
0 \\
0 \\
\text { II } \\
\text { II } \\
0 \\
\text { III } \\
\text { III } \\
\text { III }\end{array}$ \\
\hline
\end{tabular}

* Surgical intervention.

0, normal vasculature; I, fœtal pattern; II, occlusive changes few and far between; III, occlusive changes widespread. 
TABLE II

Development of Collaterals and Pulmonary Vascular Changes in Pulmonary Stenosis with Intact VentriCULAR SEPTUM

\begin{tabular}{|c|c|c|c|c|c|}
\hline Case No. & Age and sex & Pulm. stenosis & Shunts & Collaterals & Pulm. vasculature \\
\hline $\begin{array}{l}51 \\
52 \\
53 \\
54 \\
55 \\
56 \\
* 57\end{array}$ & \begin{tabular}{rc}
\multicolumn{3}{c}{ Months } \\
6 & $\mathrm{M}$ \\
6 & $\mathrm{M}$ \\
6 & $\mathrm{~F}$ \\
8 & $\mathrm{M}$ \\
9 & $\mathrm{M}$ \\
18 & $\mathrm{M}$ \\
21 & $\mathrm{M}$
\end{tabular} & $\begin{array}{l}\text { Mild } \\
\text { Mild } \\
\text { Moderate } \\
\text { Mild } \\
\text { Severe } \\
\text { Mild } \\
\text { Moderate }\end{array}$ & $\begin{array}{l}\text { None } \\
\text { A.S.D. } \\
\text { None } \\
\text { None } \\
\text { None } \\
\text { A.S.D. } \\
\text { A.S.D. }\end{array}$ & $\begin{array}{l}\text { Minimal } \\
\text { Adequate } \\
\text { Minimal } \\
\text { Adequate } \\
\text { Minimal } \\
\text { Minimal } \\
\text { Minimal }\end{array}$ & $\begin{array}{l}0 \\
0 \\
\text { I } \\
0 \\
\text { I } \\
0 \\
\text { I }\end{array}$ \\
\hline $\begin{array}{l}58 \\
59 \\
60 \\
61 \\
62 \\
63 \\
64 \\
65 \\
66 \\
67 \\
* 68 \\
69 \\
70 \\
71 \\
72 \\
* 73 \\
* 74 \\
* 75 \\
76\end{array}$ & $\begin{array}{cc}2 & \text { Years } \\
3 & M \\
3 & M \\
4 & \mathrm{M} \\
5 & \mathrm{M} \\
\mathbf{8} & \mathrm{M} \\
10 & \mathrm{M} \\
11 & \mathrm{~F} \\
12 & \mathrm{M} \\
12 & \mathrm{~F} \\
13 & \mathrm{~F} \\
14 & \mathrm{M} \\
16 & \mathrm{M} \\
17 & \mathrm{~F} \\
18 & \mathrm{M} \\
20 & \mathrm{M} \\
25 & \mathrm{M} \\
31 & \mathrm{M} \\
32 & \mathrm{M}\end{array}$ & $\begin{array}{l}\text { Severe } \\
\text { Severe } \\
\text { Severe } \\
\text { Mild } \\
\text { Severe } \\
\text { Moderate } \\
\text { Severe } \\
\text { Moderate } \\
\text { Moderate } \\
\text { Severe } \\
\text { Severe } \\
\text { Severe } \\
\text { Moderate } \\
\text { Severe } \\
\text { Moderate } \\
\text { Severe } \\
\text { Severe } \\
\text { Severe } \\
\text { Moderate }\end{array}$ & $\begin{array}{l}\text { A.S.D. } \\
\text { A.S.D. } \\
\text { A.S.D. } \\
\text { A.S.D. } \\
\text { A.S.D. } \\
\text { A.S.D. } \\
\text { P.D.A. } \\
\text { None } \\
\text { None } \\
\text { None } \\
\text { None } \\
\text { A.S.D. } \\
\text { A.S.D. } \\
\text { A.S.D. } \\
\text { P.D.A. } \\
\text { A.S.D. } \\
\text { A.S.D. } \\
\text { A.S.D. } \\
\text { A.S.D. }\end{array}$ & $\begin{array}{l}\text { Adequate } \\
\text { Adequate } \\
\text { Adequate } \\
\text { Adequate } \\
\text { Adequate } \\
\text { Adequate } \\
\text { Adequate } \\
\text { Minimal } \\
\text { Minimal } \\
\text { Minimal } \\
\text { Minimal } \\
\text { Adequate } \\
\text { Adequate } \\
\text { Minimal } \\
\text { Adequate } \\
\text { Minimal } \\
\text { Minimal } \\
\text { Minimal } \\
\text { Adequate }\end{array}$ & $\begin{array}{l}0 \\
0 \\
0 \\
0 \\
0 \\
0 \\
0 \\
\text { I } \\
\text { I } \\
\text { I } \\
\text { II } \\
0 \\
0 \\
\text { I } \\
0 \\
\text { II } \\
\text { II } \\
\text { III } \\
0\end{array}$ \\
\hline
\end{tabular}

* Surgical intervention.

0, normal vasculature; I, fœetal pattern; II, occlusive changes few and far between; III, occlusive changes widespread.

\section{RESULTS}

The bronchial arteries were well developed in most instances, particularly in the older cases. Usually one large bronchial artery and a smaller one arising from the distal part of the arch of the aorta were seen. Sometimes a patent ductus acted as a bronchial collateral. In a few cases two or more branches from the intercostal arteries were seen. In the majority of instances, the development of bronchial collaterals for patients of the same age was inversely proportional to the size of the pulmonary orifice. It depended also on age. In the newborn infant, in spite of severe pulmonary stenosis, the bronchials were not prominent; in children who had died under 1 year and in whom the pulmonary stenosis was mild, the bronchials were not prominent. The longer that a child lived with stenosis the better developed were the bronchial vessels. In a small number of cases, however, in spite of severe pulmonary stenosis and increasing age the bronchials were not adequately developed (Tables I and II).

The pulmonary vasculature in most instances appeared normal in children under 2 years of age. In older children, pulmonary vascular changes were dependent upon the degree of pulmonary stenosis and the development of bronchial collaterals. Normally, the pulmonary vessels attain adult pattern in most cases by the sixth month after birth (Civin and Edwards, 1951). By adult pattern is meant muscular arteries with thin media and wide lumen and arterioles with no muscular coat except at their origins. In cases where the pulmonary stenosis was considerable and the collaterals mild the fœtal pattern persisted for longer periods (Fig. 1 and 2) (Tables I and II). In Cases 65, 66, 67, and 71 (Table II) fœtal pattern was seen even in the eleventh, twelfth, and seventeenth 


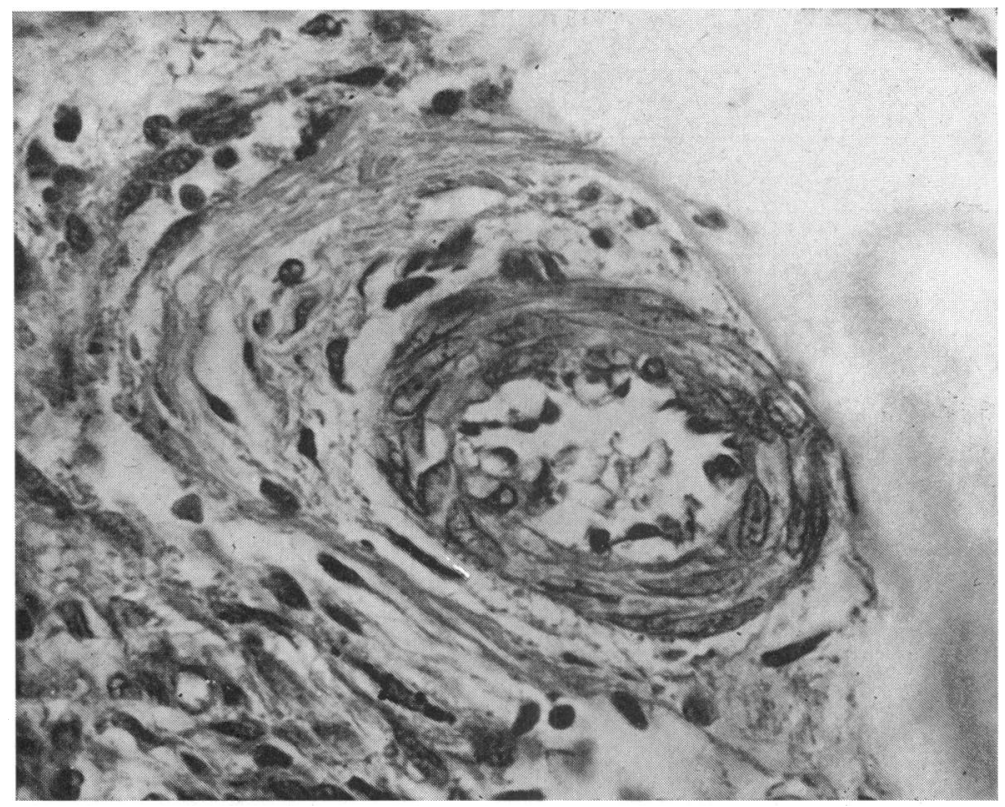

Fig. 1.- Muscular pulmonary artery from Case 35 showing thick muscular media and narrow lumen; persistent fœtal pattern (pulmonary vascular dysplasia). (H. and E. $\times 500$.)

years. Despite severe pulmonary stenosis, if the bronchial arteries were adequate, the pulmonary vessels evolved normally (Cases 10, 13, 15, 26, 31, 33, 36, 38, 58, 59, 60, 62, 64, and 69). Development of good bronchial collaterals was thus seen to be necessary for the normal evolution of the pulmonary vessels in cases with severe pulmonary stenosis.

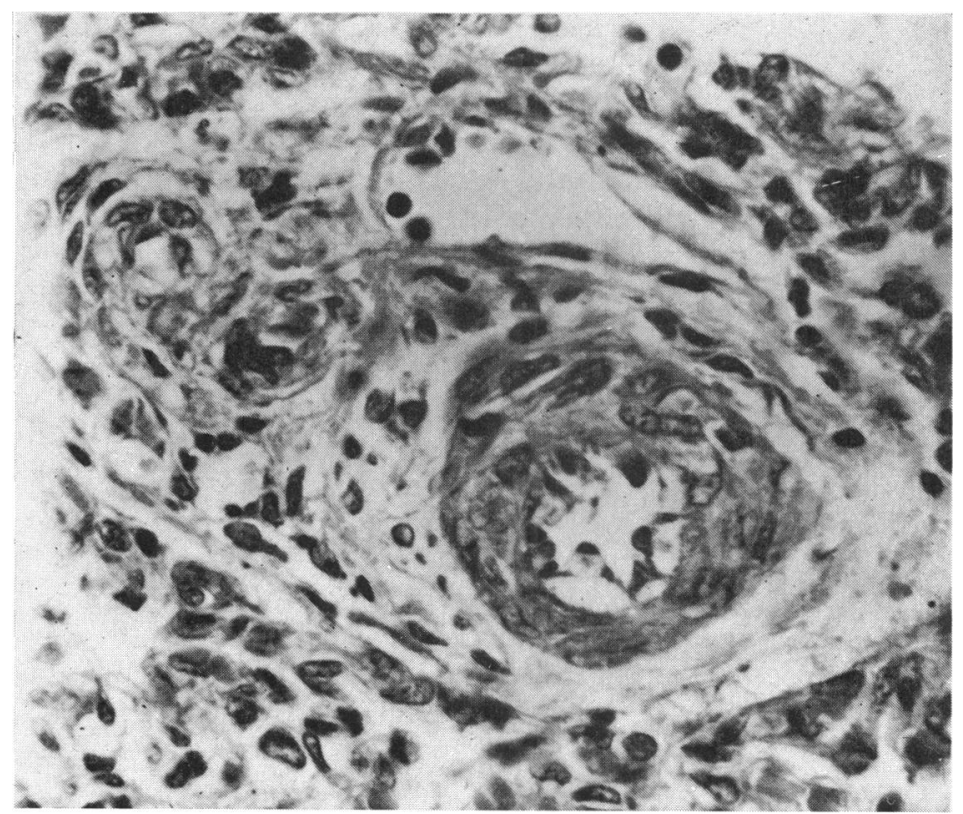

FIG. 2.-Smaller muscular pulmonary artery from Case 27 showing persistent fotal pattern (pulmonary vascular dysplasia). Arterioles also seen in the picture showing same pattern. (H. and E. $\times 500$.) 


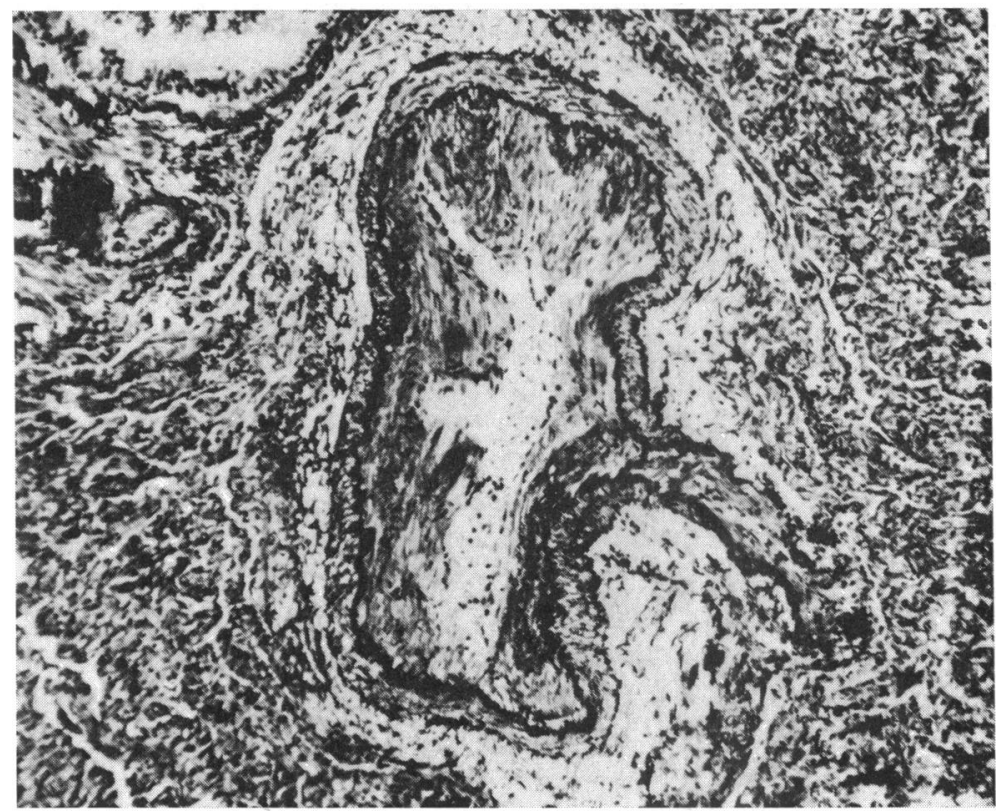

FIG. 3.-Elastic artery showing intimal proliferation, Case 49. (Verhœff-van Gieson. $\quad \times 75$.

Another abnormality found was the narrowing or occlusion of pulmonary arteries due to intimal proliferation (Fig. 3 and 4) or thrombo-embolism. The arteries affected were usually small and in the early stages the affected vessels were few and far between. The thrombo-emboli were of varying ages, some being fresh while others showed partial organization. Most of the small arteries were packed with red cells. These were interpreted as manifestations of polycythæmia and the earliest

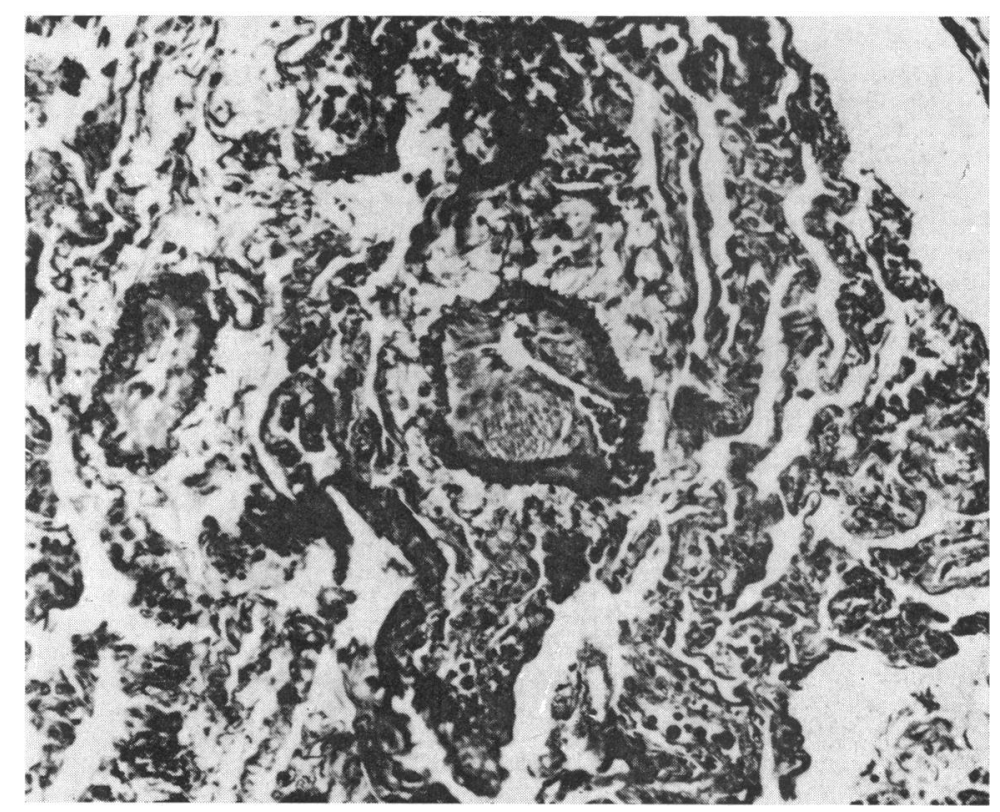

Fig. 4.-Muscular arteries showing intimal proliferation, Case 49. (Verhœef-van Gieson. $\quad \times 150$.) 
phase of thrombosis. At a later stage the proliferative and occlusive changes were widespread in the lungs and many small arteries were completely blocked. These changes were seen mainly in the second and third decades, and were prominent in cases with severe pulmonary stenosis and poorly developed collaterals. Diminished pulmonary blood flow was thus an important factor in the development of these lesions (Heath et al., 1958). The characteristics of the pulmonary vessels are shown in Tables I and II.

\section{Discussion}

One fact that emerged from the above study was the importance of the bronchial collaterals in cases with severe pulmonary stenosis. Their non-development dictated other changes in the pulmonary vasculature. These pulmonary vascular changes were twofold: (a) delayed evolution of the pulmonary vasculature from the fœtal to the adult type and (b) occlusive changes in the pulmonary vessels. The first appears to be due to inadequate blood flow through the pulmonary vessels. In cases with severe pulmonary stenosis, adequate collaterals being absent in the neonatal period, one of the factors necessary for the normal evolution of the pulmonary vessels, viz. adequate filling of the vessels, was lacking and hence the fœtal pattern persisted for longer periods. At this stage in some cases the bronchial arteries hypertrophied and provided adequate collateral circulation to the lungs. Once this occurred, the evolution proceeded normally. This compensatory development of the bronchial arteries occurred at different periods in different individuals; and this may be the reason why, in the face of moderate to severe stenosis, some cases showed persistent fotal pattern while others did not. When the bronchial arteries hypertrophied quite early (within the first few months) no persistence of the fætal pattern was seen. Sometimes, in spite of severe pulmonary stenosis, the bronchial arteries did not develop to any significant degree and in these cases the pulmonary vessels may be described as "dysplastic", retaining the fœtal structure of thick media and narrow lumen. Heath et al. (1958) in their report on thrombosis in cases of pulmonary stenosis mentioned that in cases with minimal stenosis and large ventricular septal defects the fotal pattern persisted for longer periods; and with this the author is in agreement, as shown by Cases 11 and 37. However, in such cases the more serious defect is the septal defect and not the stenosis, which is minimal. In cases where the stenosis is severe or where there is atresia, however, pulmonary blood flow is diminished, sometimes grossly so, and the delayed evolution of the pulmonary vessels in these cases is probably due to inadequate blood flow.

Thrombo-embolism in these cases was first described by Rich (1948) and later confirmed by others (Hales and Liebow, 1948; Tosetti, Actis Dato, and Angelino, 1953). Thrombo-emboli may be due to polycythæmia (Gould, 1960), diminished pulmonary blood flow (Heath et al., 1958), or vegetations from the pulmonary valves (Heath and Whitaker, 1955). In the present series it occurred almost exclusively in the second and third decades and mainly in patients with severe pulmonary stenosis and poor collaterals.

Intimal proliferation and fibrosis were due to poor blood flow and again depended on the size of the stenosis and collaterals. These changes also were prominent in the second and third decades. In cases where the collaterals were adequate and the stenosis severe intimal changes were absent (Cases 31, 33, 36, 38, 58, 59, 60, 62, 64, and 69).

Thus there appear to be two factors responsible for the various pulmonary vascular changes: (a) poor blood flow to the lung caused by severe pulmonary stenosis and poor collaterals, and (b) increasing age. None of the changes described above occurred when the bronchials were well developed; and the changes were most prominent after the second decade.

These findings indicate that surgery should be done before pulmonary vascular changes occur. When occlusive changes are irreversible and widespread, the futility of operative correction of the stenosis is obvious. The extensiveness of these changes may be judged during life by calculation of pulmonary vascular resistance from cardiac catheterization findings or perhaps by selective pulmonary angiography. Lung biopsies, when possible, may also be of help. Occlusive changes would undoubtedly increase operative and post-operative risk and diminish the chance of a good result and, when severe, operation would be contraindicated. 
Since occlusive changes were infrequent before 15 years and severe after 20 years of age any corrective surgery that is intended is best done before the fifteenth year of life. Such an operation at too early an age is also not recommended because the pulmonary arteries may be dysplastic if the bronchial collaterals are not well developed. Hence it is felt that the complete corrective operation should be deferred till the fifth year, by which time, in most cases, the bronchials, if they are going to develop at all, are best developed. If a child with tetralogy of Fallot is extremely cyanotic, a shunt operation could be done at a very early age thus allowing the pulmonary vessels to evolve normally and a complete corrective procedure may be done after the fifth year of life. If, radiologically, the pulmonary vascular markings indicate adequate collateral circulation, earlier surgical correction may be feasible.

\section{SumMaRY AND CONCLUSIONS}

The status of bronchial arterial collateral circulation and the pulmonary vasculature in 50 cases of pulmonary stenosis with ventricular septal defect and 26 cases of pulmonary stenosis with intact ventricular septum, ranging in age from 1 month to 32 years, were studied at necropsy. Occlusive changes in pulmonary vessels were present in cases over 15 years of age in whom bronchial collaterals were poorly developed. Hence it is concluded that corrective surgery should be performed before the fifteenth year. The importance of bronchial collaterals for the proper evolution of pulmonary vasculature in cases of severe pulmonary stenosis is stressed. Since the bronchial collaterals are seldom well developed before the age of 5 years, it is suggested that corrective surgery be deferred until this age is reached.

The author wishes to thank Professor K. Shanmugaratnam for his help and encouragement in writing this paper, Mr. V. Nalpon for the photographs, and Mr. P. A. Samuel for typing the manuscript.

\section{REFERENCES}

Civin, W. H., and Edwards, J. E. (1951). The postnatal structural changes in the intrapulmonary arteries and arterioles. A.M.A. Arch. Path., 51, 192.

Dammann, J. F., and Ferencz, C. (1956a). The significance of the pulmonary vascular bed in congenital heart disease. I. Normal lungs. II. Malformations of the heart in which there is pulmonary stenosis. Amer. Heart J., 52, 7 .

, and - (1956b). The significance of the pulmonary vascular bed in congenital heart disease. III. Defects between the ventricles or great vessels in which both increased pressure and blood flow may act upon the lungs and in which there is a common ejectile force. Amer. Heart J., 52, 210.

Edwards, J. E. (1957). Functional pathology of the pulmonary vascular tree in congenital cardiac disease. Circulation, 15, 164.

Gould, S. E. (1960). Pathology of the Heart, 2nd ed., p. 328. Charles C. Thomas, Springfield, Illinois.

Hales, M. R., and Liebow, A. A. (1948). Collateral circulation to the lungs in congenital pulmonic stenosis. Bull. int. Ass. med. Mus., 28, 1.

Heath, D., DuShane, J. W., Wood, E. H., and Edwards, J. E. (1958). The ætiology of pulmonary thrombosis in cyanotic congenital heart disease with pulmonary stenosis. Thorax, 13, 213.

, and Whitaker, W. (1955). The pulmonary vessels in patent ductus arteriosus. J. Path. Bact., $70,285$.

Rich, A. R. (1948). A hitherto unrecognized tendency to the development of widespread pulmonary vascular obstruction in patients with congenital pulmonary stenosis (tetralogy of Fallot). Bull. Johns Hopk. Hosp., 82, 389.

Tosetti, R., Actis Dato, A., and Angelino, P. F. (1953). Histo-pathologie des petits vaisseaux pulmonaires dans les sténoses congénitales de l'artère pulmonaire. Arch. Mal. Caur, 46, 780. 